\title{
A replacement name for the bee Euhesma sulcata Exley (Hymenoptera: Colletidae: Euryglossinae)
}

\author{
Elizabeth M. Exley $\dagger$ \\ Department of Zoology and Entomology, The University of Queensland, \\ St Lucia, Queensland 4072, Australia
}

\begin{abstract}
Euhesma stria is proposed as a replacement name for Euhesma sulcata Exley 2002 which was found to be a junior secondary homonym of Euhesma sulcata (Exley 1998).
\end{abstract}

\section{INTRODUCTION}

Exley (2002) proposed the name Euhesma sulcata for a new bee species of the Euhesma crabonica species-group from Western Australia. This species has been found to be preoccupied by Euhesma sulcata (Exley, 1998), which was originally described as Euryglossa (Euhesma) sulcata. The subgenus Euhesma was raised to generic level by Michener (2000). A replacement name for the preoccupied name is provided below.

\section{Euhesma stria, nom. nov.}

Euhesma sulcata Exley, 2002: 208, figure 4. Junior secondary homonym of Euhesma sulcata (Exley, 1998).

\section{Etymology}

The Latin word stria, meaning furrow, refers to the same structure as the original E. sulcata, i.e. the groove-like metasomal foveae.

\section{ACKNOWLEDGEMENT}

I am very grateful to Michael Batley for alerting me to the homonymy.

\section{REFERENCES}

Exley, E.M. (1998). New Euryglossa (Euhesma) bees (Hymenoptera: Colletidae: Euryglossinae) associated with the Australian plant genus Eremophila (Myoporaceae). Records of the Western Australian Museum 18: $419-437$.

Exley, E.M. (2002). Bees of the Euhesma crabonica species-group (Hymenoptera: Colletidae: Euryglossinae). Records of the Western Australian Museum 21 203-211.

Michener, C.D. (2000). The bees of the world. John Hopkins University Press: Baltimore.

Manuscript accepted 6 July 2007

+ Deceased 2 September 2007 


\section{Guide to Authors}

\section{Subject Matter:}

Reviews, observations and results of research into all branches of natural science and human studies will be considered for publication. However. emphasis is placed on studies pertaining to Western Australia. Longer papers will be considered for publication as a Supplement to the Records of the Western Australian Museum. Short communications should not normally exceed three typed pages and this category of paper is intended to accommodate observations, results or new records of significance. that otherwise might not get into the literature, or for which there is a particular urgency for publication. All material must be original and not have been published elsewhere.

\section{Presentation:}

Authors are advised to follow the layout and style in the most recent issue of the Records of the Western Australian Museum including headings, tables. illustrations and references.

The title should be concise, informative and contain key words necessary for retrieval by modern searching techniques. An abridged title (not exceeding 50 letter spaces) should be included for use as a running head.

An abstract must be given in full length papers but not short communications, summarizing the scope of the work and principal findings. It should normally not exceed $2 \%$ of the paper and should be suitable for reprinting in reference periodicals.

The International System of units should be used.

Numbers should be spelled out from one to nine in descriptive text; figures used for 10 or more. For associated groups, figures should be used consistently, e.g., 5 to 10, not five to 10.

Spelling should follow the Concise Oxford Dictionary.

Systematic papers must conform with the International Codes of Botanical and Zoological Nomenclature and. as far as possible, with their recommendations.

Synonymies should be given in the short form (taxon, author, date page) and the full reference cited at the end of the paper. All citations. including those associated with scientific names. must be included in the references.

\section{Manuscripts:}

The original and two copies of manuscripts and figures should be submitted to the Editor. o/ Publications Department. Western Australian Museum. Locked Bag 49. Welshpool DC. Western Australia 6986. They must be in double-spaced typescript on A4 sheets. All margins should be at least $30 \mathrm{~mm}$ wide. Tables plus heading and legends to illustrations should be typed on separate pages. The desired position for insertion of tables and illustrations in the text should be indicated in pencil. Tables should be numbered consecutively, have headings which make them understandable without reference to the text, and be referred to in the text.

High quality illustrations are required to size $(16.8 \mathrm{~cm} \times 25.2 \mathrm{~cm})$ or no larger than $32 \mathrm{~cm} \times 40$ $\mathrm{cm}$ with sans serif lettering suitable for reduction to size. Photographs must be good quality black and white prints, not exceeding $16.8 \mathrm{~cm} \times 25.2 \mathrm{~cm}$. Scale must be indicated on illustrations. All maps. line drawings, photographs and graphs, should be numbered in sequence and referred to as Figure/s in the text and captions. Each must have a brief. fully explanatory caption. On acceptance a computer disk containing all corrections should be sent with amended manuscript. The disk should be marked with program (e.g. Word, WordPerfect, etc).

In papers dealing with historical subjects references may be cited as footnotes. In all other papers references must be cited in the text by author and date and all must be listed alphabetically at the end of the paper. The names of journals are to be given in full.

\section{Processing:}

Papers and short communications are reviewed by at least two referees and acceptance or rejection is then decided by the editor.

The senior author is sent one set of page proof which must be returned promptly.

The senior author will receive fifty free offprints of the paper. Additional offprints can be ordered at page proof stage. 


\section{Records of the Western Australian Museum Volume 24 Part 22008}

\section{CONTENTS}

\section{Melinda L. Moir and Mark S. Harvey}

Discovery of the pill millipede genus Epicyliosoma (Diplopoda:

Sphaerotheriida: Sphaerotheriidae) in Western Australia, with the

description of a new species

Paul Doughty and Danielle Edwards

A new species of Arenophryne (Anura: Myobatrachidae) from the central

coast of Western Australia

\section{Marion Anstis}

Direct development in the Australian myobatrachid frog

Metacrinia nichollsi from Western Australia

\section{Martin Baehr}

New and rare pseudomorphine species from Western Australia

(Insecta, Coleoptera, Carabidae, Pseudomorphinae)

Yu Wen

On the genus Yangtzemerisma and related genera

(Mollusca: Merismoconchia)

\section{Christer Erséus}

A new species, Olavius ulrikae (Annelida: Clitellata: Tubificidae),

re-assessment of a Western Australian gutless marine worm

\section{Martin Baehr}

A new cavernicolous and eyeless species of the genus Lymnastis from

Christmas Island, Australia (Insecta: Coleoptera: Carabidae: Bembidiinae)

\section{Dirk Fehse and Jozef Grego}

New species of the genus Trivellona (Mollusca: Gastropoda) from the Miocene of Australia

\section{Elizabeth M. Exley}

A replacement name for the bee Euhesma sulcata Exley

(Hymenoptera: Colletidae: Euryglossinae) 